\title{
Esnaflar Arası Komşuluk İlişkileri: Konya Bedesten Çarşısı Üzerine Bir Değerlendirme
}

\author{
Neighborhood Relations Between Tradesmen: An Evaluation on Konya Bedesten Bazaar \\ Uğur Çağlak ${ }^{a, *}$ \\ ${ }^{a}$ Dr. Ögr. Üyesi, Necmettin Erbakan Üniversitesi, Sosyal ve Beşeri Bilimler Fakültesi, Halkla İlişkiler ve Reklamcılık Bölümü, Konya/Türkiye \\ ORCID: 0000-0002-6750-8621
}

\section{MAKALE BİLGISİ}

\section{Makale Geçmişi:}

Başvuru tarihi: 03 Temmuz 2020

Düzeltme tarihi: 17 Ağustos 2020

Kabul tarihi: 24 Ağustos 2020

\section{Anahtar Kelimeler:}

Komşu

Komşuluk

Esnaf Komșuluğu

Kültür

Sosyalleşme
ÖZ

Toplumdaki her insan birbiriyle, çevresiyle etkileşim içindedir. Etkileşim olmadan bireyin sosyal hayatta varlığı neredeyse imkânsız gibidir. Aile, akrabalık, iş yeri, okul ve daha birçok kurumda resmi ya da gayri resmi bir şekilde etkileşim içinde olan insan, komşuluk ilişkisi de kurmaktadır. Komşuluk özellikle kent hayatında kendisine duyulan ihtiyaçtan ve de toplumsal hayattaki işlevi açısından dolayı sosyal bilimler alanında daha fazla yer tutmaya, daha fazla tartışılmaya başlamıştır. Bu çalışmada da toplum hayatının önemli bileşenlerinden biri olan komşuluğun, esnaf komşuluğu ekseninde bir değerlendirmesi yapılmaktadır. Bu bağlamda yüz yüze görüşme tekniği kullanılarak Konya ilindeki bedesten çarşısında bulunan esnaflar ile nitel bir çalışma yapılmıştır. Araştırmada esnaf komşuluğu bağlamında komşuluk algısı ve duygusu, komşuluk ilişkileri ve de komşuluk ilişkilerinin değişim ve dönüşümünü anlamak ve yorumlamak amaçlanmaktadır. Çalışma sonucunda esnaflar arasında komşuluk ilişkilerinin devam ettiği ancak son zamanlarda komşuluk ilişkilerinin azalarak daha yüzeysel bir zemine oturduğu görülmektedir.

\section{AR T ICLE INFO}

\section{Article history:}

Received 03 July 2020

Received in revised form 17 August 2020

Accepted 24 August 2020

\section{Keywords:}

Neighbor

Neighborhood

Shopkeepers Neighborhood

Culture

Socialization

\section{AB S TR ACT}

People in the community interact with each other. Without interaction the individual seemed almost impossible to exist in social life. Interacting in a formal or informal way in the family, kinship, work, school and many other institutions, people also establish a neighbourly relationship. Neighborhood has started to take more place in the social sciences and discussed more, especially in terms of the need for it in urban life and its function in social life. In this study, an evaluation of the neighbourhood, which is one of the important components of the community life, is made of the axis of shopkeepers. In this context, a qualitative study was carried out with the shopkeepers in the Bazaar of Konya, via face to face interview technique. In this research, it is aimed to understand and interpret the perception and sense of neighbourhood, neighbourhood relations as well as the change and transformation of neighbourhood relations in the context of neighbourhood of shopkeepers. As a result of the study, it is seen that neighbourly relations continue between the shopkeepers but recently the neighbourhood relations have decreased and settled on a more shallow ground.

\section{Giriş}

Uygarlık tarihinin başlangıcı olarak kabul edilen kentsel mekânlar insanların toplu olarak yaşadığı farklılıkları barındıran bir mekândır. Çok farklı sınıflardan, kültürlerden, inançlardan, dinlerden, dillerden gelen kentin ana unsuru olan insan, kentte toplu yaşamın gereğini yerine getirme ihtiyacı da hissetmektedir. Kent, sadece yapılarıyla var olan bir mekân değil aynı zamanda bir ilişkiler sisteminin gerçekleştiği bir alandır. Alver'in dediği gibi (2012: 9), "kent insanlık tarihinin belli bir anında ve belli koşullarla oluşan ve sosyal, kültürel, iktisadi, tarihsel, dini, mimari, estetik yönüyle temayüz eden bir yaşam alanıdır”. Bir yaşam alanı olan kente ilişkin bir değerlendirme yapılıyor ise bu değerlendirme kentin sadece temayüz eden fiziki, coğrafi, mekânsal özelliklerinde değil aynı zamanda

\footnotetext{
* Sorumlu yazar/Corresponding author

e-posta: ucaglak@konya.edu.tr
} 
kentin kültürel ögelerine, değerler sistemine göndermede bulunularak yapılmaktadır. Kent hayatında çok farklı sosyal ilişkilerde bulunan insan, belki de en önemli sosyal ağlardan bir tanesini komşuluk bağı ile kurmaktadır. Kent sadece yapısal olarak bir bütün değil aynı zamanda hayatın da ta kendisidir.

Belki de biraz önce kent incelemesinde ayrımı yapılan "yapı ve hayat" itibari ile yapılan değerlendirmede "komşu" yapisal olarak incelemenin biraz daha mekânsal, fiziksel yönüne tekabül ederken, "komşuluk" hayata ilişkin değerlendirmelere tekabül etmektedir. Komşu, ev, iş yeri, arazi, şehir, ülke gibi fiziki yapıların kendi içlerinde, mekânsal fiziksel olarak yakınlıklarından dolayı almış oldukları konumlardır. Her şeyden önce komşu fiziksel olarak bir yakınlığı ifade etmektedir. Aynı zamanda komșu fiziksel yakınlığın ötesinde sosyal bir ilişki sistemine de atıfta bulunmaktadır. Bu da "komşuluk" veya "komşuluk ilişkileridir". Akraba ilişkileri, aile ilişkileri, ekonomi temelli ilişkiler gibi komşuluk da bir ilişki sistemidir.

Komşuluk dendiği zaman ilk olarak aynı mahallede oturan, aynı sokağ1 veya aynı siteyi, apartmanı paylaşan insanlar arasındaki bir ilişki alanı, yani ev komşuluğu akla gelmektedir. Ancak komşuluk sadece mekânsal olarak insanların ikamet ettiği bir alanı kapsamaz. Bu alan ikamet alanın olduğu ev, apartman komşuluğu olabileceği gibi, bir mahalle, arazi, köy, şehir, ülke hatta bir dükkân komşuluğu olabilmektedir. Bir ev başka bir eve, bir iş yeri başka bir iş yerine, bir mahalle başka bir mahalleye, bir ülke başka bir ülkeye büyük bir ihtimalle komşu olabilmektedir. Coğrafi olarak tanımlarken komşu mahalle, komşu köy, komşu şehir, komşu ülke, komşu dükkân çokça kullanılan tabirlerdir. Bu tabirler mekânsal bir yakınlığı ifade etse de bunun ötesinde yakınlıkla bağlantılı olarak bir ilişki alanını da ifade etmektedir. Komşuluk mekansal ve ilişkisel bir ilişki ağını ifade eder. Dinlerde özellikle İslam dininde ve birçok farklı metinde komşuluk akrabalık kadar olmasa da akrabalığa yakın bir ilişki ağı sistemi görülebilmektedir. "Akrabalık kandaş bir yakınlık iken komşuluk mekansal bir yakınlıktır. Esasen komşuluk, aile ve akrabalarla diğer insanlar arasında bir yerde bulunur, aileden ve onunla irtibatlı akrabalıktan sonra en önemli ilişki biçimidir. Onun için de kısaca komşuluk mekansal akrabalık, akrabalık da kan bağına dayalı komşuluktur, denebilir" (Aydın,2013: 38).

Araştırmanın esas konusu olan esnaf komşuluğu da ilişki ağ1 sisteminde önde gelen komşuluk türlerindendir. İnsanlar geçmişten günümüze ekonomik hayatı sürdürebilmek için aynı, benzer ya da farklı iş kollarında mekansal olarak ortaklıklar yaşamak zorunda kalmış ve ekonomik hayat için bu bir gereklilik olmuştur. Özelikle kentsel alanlarda bedestenler, çarşılar, iş hanları, günümüzde AVM'ler, sanayi bölgeleri kurulmuştur. Bir kümelenme yaşayan ekonomi grupları aynı mekânı paylaşmış ve o mekân üzerinde bir komşuluk ilişkisi kurmuşlardır. Tıpkı mahalle komşuluğu gibi dükkân komşuluğu da benzer avantaj ve dezavantajları ile değerlendirilebilmektedir. Bu çalışmada komşuluk ekseninde esnaf komşuluğu üzerine bir araştırma yapılarak değerlendirmeye çalışılmıştır. $\mathrm{Bu}$ çalışmada özellikle komşuluk algısı ve duygusu, komşuluk ilişkileri ve de komşuluk ilişkilerinin değişim ve dönüşümünün analizinin yapılması amaçlanmaktadır. Bu bağlamda nitel bir yöntem olan görüşme tekniği kullanılarak esnaf komşuluğu incelenmeye çalışılmıştır. Ayrıca araştırma sadece Konya Bedesten Çarşısı örnekleminde uygulanmıştır.

\section{Komşuluğun Toplum Hayatındaki Yeri}

Komşuluk mekânsal yakınlık temelinde kurulan bir sosyal ilişki ağıdır. Mekânın bir iletişim alanı olarak var olma yollarında birisidir. Komşuluk "sınır komşuluğu-yan komşuluk, alt-üst komşuluk ve yakın-uzak komşuluk türleri ile değerlendirilebilmektedir" (Savaş, 2014: 122). Sınır komşuluğu komşuluğun ilk biçimidir. Özellikle arazi komşuluğu üzerinden ortaya çıkmıştır. Alt-üst komşuluk ise daha çok kentsel alanlarda çok katlı binaların yaygınlaşması ile birlikte ortaya çıkmıştır. Yakın-uzak komşuluk ise komşuluğu mekansal olarak yakınlık-uzaklık ölçüsünde değerlendirme açısından tanımlanmıştır. Ancak yakın ve uzaklık kavramı ilişki ağı içerisinde samimiyeti, muhabbeti de ifade eden bir kavramdır. Daha samimi, daha içli dışlı komşuluklara da yakın komşu tabiri kullanılabilmektedir. Komşuluk sayesinde insanlar paylaşmayı, dayanışmayı, iletişimi, mubabbeti, sosyalleşmeyi, toplumsal kontrolü ve çevresel güvenliği sağlama imkanına kavuşabilmektedirler. Zaman zaman bir çatışma alanına dönse de komşuluk genellikle iyi tarafları ile gözlemlenen bir olgudur.

Komşuluk fiziksel bir yakınlıktır. Birbirine yakın olandır. Evde, işyerlerinde, mahallede, şehirlerde hatta ülkelerde fiziksel yakınlık söz konusudur. Bu fiziksel yakınlık çok zaman aynı atmosferi solumayı, aynı ortamlarda yaşamayı, aynı toprak parçasını ve doğayı görmeyi, aynı sesleri duymayı ve benzer toplumsal yapılarda bulunmayı ifade eder. Çok zaman fiziksel benzerlikler toplumlarda benzer iş kollarının, benzer yaşam biçimlerinin, benzer reflekslerin ortaya çıkmasına neden olmaktadır. Dolayısıyla da insanlar benzer toplumsal şartlar içinde yaşamaktadırlar. $\mathrm{Bu}$ da onların hayatlarına, mekansal yapılarına, toplumsal durumlarına sirayet etmektedir. Dolayısıyla aynı mekânı paylaşan insanların pek çok ayniliği yaşadığı bir gerçektir. Komşuların da bulunduğu çevre içerisinde paylaştığ mekânda pek çok aynilik söz konudur. Komşuluk bir bakıma ayniliklerin yaşandığı bir alandır.

$\mathrm{Bu}$ ayniliklerin yaşandığı mekânda insanlar sık sık çevresi ile iletişime geçmektedir. Sosyal bir varlık olan insan kendi ailesinden başka çevrelerle de ilişki kurmak zorundadır. $\mathrm{Bu}$ ilişki ya da iletişim bireysel olabileceği gibi kolektif bir şekilde de gerçekleşebilir (Koyuncu, 2013: 10). Akrabalık ilişkileri, komşuluk ilişkileri bu minvalde olan ilişki türlerindendir. İnsanlar komşusu ile konuşmak; komşusuna selam vermek durumundadır. Benzer sorunları, benzer iyilikleri paylaşan komşular çok zaman birbiri ile iletişim içindedir. $\mathrm{Bu}$ iletişim de komşuluğu toplumsallaşmanın aktörlerinden biri haline getirmektedir. "Toplumsallaşma, toplumsal çevreye aidiyetin oluşması ve oluşan aidiyetin sürekli kurulan ilişkilerle üretilmesi demektir. Aidiyetin üretilmesi ise iletişim, enformasyon ve bilgi akışı üzerinden gerçekleşmektedir. Normlar, değerler, inançlar gibi kültürel gerçekliğin en önemli kurumsal unsurları çocukluk döneminden itibaren ailede, mahallede ve diğer sosyal çevrede öğrenilmektedir" (Akın, 2014: 75). Komşuluk içinde de çocuklar, gençler, aileler toplumsal alan içerisinde birbiri ile iletişime geçmek durumundadır. Komşu çocuklar diğer komşu çocukları ile oynar, gençler muhabbet eder, hanımlar, aileler birbirlerini ziyaret ederler. Dolayıla bir 
sosyalleşme alanı olarak görülen komşuluk müessesi insanların toplumsal olarak değerleri, inançları, normları edindiği, öğrendiği bir kurum olarak da görülebilmektedir. Komşuluk aynı zamanda toplumsal bir kurumdur.

Sosyal bir kurum olan komşuluk sosyalleştirici bir öğe olarak çok zaman paylaşmanın ana aktörlerinden biri olabilmektedir. Aynı mekânı paylaşan insanlar zorlukları, kolaylıkları, iyilik ve kötülükleri dahası pek çok şeyi paylaşmaktadır. Komşuluk ile çevrenin, insanların, hayatın getirmiş olduğu zorluklar paylaşılarak beraberce aşılabilmekte ve işler kolaylaşabilmektedir. Komşuluk sayesinde bir dayanışma ruhu ortaya çıkabilmektedir. Düğünler, cenazeler, asker uğurlamaları, bayramlar, mutluluklar, neşeler, acılar, hüzünler paylaşılabilmektedir. Dahası "komşu komşunun külüne muhtaçtır" minvalinde insanlar mekanlarında bulunan yiyecekleri, içecekleri ve pek çok şeyi paylaşmakta ve dayanışma ile birlikte karşılıklı güven duygusunu sağlayabilmektedir.

Karşılıklı güvenin ve çevresel güvenliğin sağlanması komşuluğun ana bileşenlerinden birileridir. Yardımlaşma, dayanışma, paylaşma ve karşılıklı iletişim ile sağlanan karşılıklı güven sonucunda aile veya bir yapı düzeyinde komşular, birbirleri arasında rahat hareket edebilmelerinin imkanına kavuşmaktadırlar. Mahalle kültürünün, esnaf kültürünün ve daha geleneksel ilişkilerin yaygın olduğu toplumsal yapılarda hem karşılıklı güven hem de güvenlik meselesi resmi kurumların aktif katılımı ile birlikte belki de daha fazla kendi toplumsal yapıları içinde çözümlenebilmektedir. Toplumsal yapılar bir sosyal kontrol mekanizması görevini yerine getirirken güvenliği de sağlayabilmektedir.

Birçok toplumsal yapıda olduğu gibi komşuluk ilişkilerinde de bazen büyük ya da küçük ölçekte çatışmalar da yaşanabilmektedir. Kendi değerlerini, inançlarını ve normlarını üretmiş komşuluk kültürünün hâkim olduğu geleneksel toplum yapılarında sosyal kontrol komşular eliyle de yapılabilmektedir. Çok zaman "laf olur, ayıp olur, ele güne karşı, konu komşu ne der” sözlerinde temayüz eden komşuluk ilişkileri, bu minvalde kendi toplumsal ilişkiler ağı içerisinde değerler, normlar ve özellikle kanaat önderlerinin çözüm bulmadaki rolü ile sorunlara çözüm getirilebilmektedir. Küçük ölçekteki problemleri kendi içlerinde, büyük ölçekteki problemlerde ise genellikle resmi kanallarla çözüm bulmaya çalışılan komşular arası problemler, özellikle modern ilişkilerin yaygın olduğu toplumlarda problemin boyutuna bakılmadan resmi kanallar ile çözümlenebilmektedir. $\mathrm{Bu}$ da geleneksel toplumlarda daha çok sözlü, modern toplumlarda ise daha çok yazılı bir şekilde komşuluk hukukunun ortaya çıkmasına neden olmaktadır. Ancak her iki toplum yapısında da resmi ve gayri resmi biçimde çözüm yollarının var olduğu görülebilmektedir.

Komşuluk hukukuna bakış daha çok resmi düzenlemeler ve katlanma yükümlülüğü üzerinedir. Resmi düzenlemeler, komşular arası olası muhaliflikleri düzenlemek amacıyla belirli yazılı kurallar ölçüsünde yasaklamalar üzerine kuruludur. Arazi hakkı, su hakkı gibi muhtelif konular bu şekilde çözüme ulaştırılmaya çalışılmıştır. Katlanma yükümlüğü ise komşunun taşınmazı kullanımı sırasında oluşan koku, duman, is, ses ve gürültü çıkarmak gibi etkilerin, içinde bulunulan sosyal çevredeki örf ve adete göre düzenlenmesidir ve bu durumlarda düzenlenemeyen ve mutad kullanım hallerini aşan koşullarda ise resmi hukukun devreye girmesini ifade eder (Savaş, 2014: 145).

Komşuluk ilişkileri bir şekilde gruplar arasında bir bağdır. Grup bağları özellikle dayanışma ruhunun yaygın olduğu toplumlarda çok daha etkindir. Dayanışma ruhunun etkin olduğu toplumlarda "sorumluluk, fedakârlık ve uzlaşmaya, bireysel öz güven ve başarıdan daha büyük değer atfedilir. Grup bağlarının, bireyin mutluluğu için en önemli unsur olduğu kabul edilir. $\mathrm{Bu}$ nedenle grup bağlarının yüksek olduğu toplumlarda gruba bağlılık ve sorumluluk duygusu en üst düzeydedir" (Newman, 2016: 93). Ancak modernleşmenin ve bireyselleşmenin yoğun olarak hissedildiği günümüzde modernleşme ve bireyselleşme ile birlikte bireyin toplumdan yalıtıldığı, aktif katılımın seyreltildiği ve sosyal güven düzeyinin azaldığı tartışılmaktadır. Dayanışma ruhunun yüksek olduğu toplumsal yapılarda bile bu durum izlenebilmektedir. Komşuluk ilişkileri de bu durumdan nasibini alabilmekte ve komşuluk ilişkileri zayıflayıp dejenere olabilmektedir. Dolayısıyla son zamanlarda yoğun bir şekilde tartışılan sosyal sermaye teorisi içersinde de komşuluk ilişkileri tartışılmaktadır.

Komşuluk birbirlerini tanıyan ya da aşina olan kişilerin devam eden ilişkiler ağı, davranışlar bütünüdür. Komşuluk alanında "insanların birbirleriyle sürekli karşılaşmaları ve paylaşımlarda bulunmaları aşinalık, mütekabiliyet, güven sahiplik ve ortaklık duygusu gibi toplumu örgütleyen, bütünlüklü bir yapıya dönüştüren zemini üretir. Ayrıca sınırlı bir toplumsal alanda tanınırlık, itibar, güvenirlilik gibi kişi, aile ve toplulukların sahip olduğu sosyal sermaye rezervleri hayatı kolaylaştıran ve karşılaşılan sorunların aşılmasında işılevsel olarak kullanılabilen ağları inşa etmelerini sağlar" (Aydemir, 2014: 164). Dolayısıyla komşuluk sosyal sermaye alanının bir öznesi olarak değerlendirilebilmektedir.

Bir olgu olarak komşuluk paylaşma, dayanışma, yardımlaşma, ortaklaşa kullanım ve sosyal kontrol üzerine kurulu toplumsal bir kurumdur. Bir anlamda komşuluk toplumsal ilişkiler ağı içerisinde ve mekân üzerinde bir nevi ilişkisel ortaklık kurma halidir. Bu hali ile sosyal sermaye alanının da konusu olabilen komşuluk zaman zaman iyiliklerin, güzelliklerin yaşandığı bir alan olabilirken zaman da çatışmaların yaşandığı bir alan olabilmektedir. Çatışmalar kimi zaman toplumsal çevre içerisinde aşılabilirken kimi zaman da resmi kurallar bütünü içerisinde çözüme kavuşabilmektedir.

\section{Esnaf, Esnaf İlişkileri ve Dükkân Komşuluğu}

Geçmişten günümüze kadar uzanan bedestenlerde, çarşılarda, cadde üzerilerinde ve mahallelerde ve pazar alanlarında yoğun olarak bulunan esnaflar ekonomik bir ünite olarak ekonomik hayatın can damarlarından biridir. "Esnaf, Arapça 'bir kelime olup «sınıf» kelimesinden gelmektedir. Esnafi, demircilik, bakırcılık, oymacilık vb. gibi küçük el zanaatları ya da bakkallık, manifaturacılık, tuhafiyecilik vb. gibi küçük ticarî faaliyetlerle uğraşan zümreler olarak tanımlamak mümkündür" (Özdemir, 1986: 156). 
Esnaflar ekonomik hayatın ana aktörlerinden biridir. Özellikle kendi kol gücüne veya ufak çaptaki makineler ile üretilen ürünleri ya da diğer tedarikçilerden satın aldıkları ürünleri satan ticaret erbaplarıdır. Esnaflar ülke çapında yaygın bir meslek grubu olmaları ve de her esnaf dükkanında az sayıda da olsa çalıştırdıkları tezgahtar gibi elemanları hasebiyle istihdamı emme potansiyelleri bulunmaktadır. Ayrıca önemli ölçüde de ülkeye katma değer ekleyebilmektedirler. Esnaflar "ekonomik dalgalanmalara karşı dayanıklılık gösteren ve piyasanın taleplerine nispeten daha hızlı cevap verebilen esnek bir yapıya sahiptirler. Türk ekonomisinde de önemli bir yeri olan esnaf ve sanatkârlar, kendi emeğini küçük miktardaki sermayesiyle birleştirerek piyasada yer edinmeye çalışmakta ve ülkedeki işsizlik sorununa, üretime, piyasaların işlemesine dolayısıyla ülke ekonomisine katkıda bulunmaktadır" (Çoban ve İrmiş, 2015: 31). Aynı zamanda usta çırak ilişkisi açısından esnaf önemli bir mekteptir. Tezgahtarlar işletme sahibinden iletişimi, pazarlamayı, borçlanmayı, alacakları tahsil etmeyi ve dahası iş ahlakını öğrenebilmektedirler.

Esnaflar sosyal hayatında önemli aktörlerindendir. Özellikle müşteri ile olan ilişkileri açısından farklı konumdadır. Esnaf, çarşıda, pazarda, bedestende, mahallede yüz yüze görüşülen kişidir. Çok zaman esnaf müşteriyi, müşteri esnafi tanır ve zaman zaman esnaf müşteri ilişkileri samimi, içten bir zemine oturur. Esnaf müşterisine hal, hatır sorar, ikramda bulunur ve hayata dair sohbette bulunur. Dolayısıyla esnaf dükkânı bir tür sosyalleşme alanı olabilmektedir.

Esnaf sadece müşteri ile iletişimi olan kişi değildir. Esnaf çevresi ile de ilişki içindedir. Mahalleli ile, komşu dükkanlar ile, cami cemaati ile ve çevresinde bulunan çay ocağ1, kıraathane gibi mekanların müdavimleri ve müşterileri ile iletişimi içindedir. Dolayısıyla esnaf kendi iş ilişkileri ağının ötesinde iş yeri çevresinde de sosyal hayatın bir öznesi konumunda bulunmaktadır. Araştırmanın ana konusu olan dükkân komşuları da esnafların iş yeri çevresinde en sık iletişimde bulunduğu ilişki ağları gruplarıdır. Yardımlaşma ekseninde dükkân komşuları işlerin yoğun olduğu zamanlarda birbirine yardım etme, elemanlardan destek alma gibi işlemlerin yanı sıra ekonomik olarak sıkıntılı zamanlarda maddi olarak yardım etme gibi faaliyetleri yerine getirebilmektedirler. Ayrıca paylaşma ekseninde yemek, temizlik, güvenlik gibi iş yerlerinin bakımı, korunumu konusunda paylaşımlarda bulunurken acıyı, neşeyi, eğlenceyi, boş zamanı da birlikte paylaşabilmektedirler. Dükkân komşuları özellikle asker uğurlama, birbirinin düğün ya da cenaze törenleri katılma ve komşuluk ilişkilerinin daha sağlıklı bir şekilde tesisi için iş yerleri ziyaretlerinde bulunmaktadırlar. Dolayısıyla ahlaki, dini ve insani bir görev olarak görülen komşuluk vazifesi yerine getirilebilmektedir.

Tipkı mahalle komşuluklarında olduğu gibi esnaf komşuluğunda da zaman zaman çatışmalar yaşanabilmektedir. Alan ihlalleri, yoğun yaşanan rekabet, ikili ilişkilerde yaşanan problemler gibi daha pek çok neden komşular arasında çatışmalara neden olabilmektedir. Bazen kendi ilişkileri içerinde çözümlenen problemler bazen de hukuki yollar vasıtası ile çözüme kavuşabilmektedir.

\section{Araștırmanın Yöntemi}

$\mathrm{Bu}$ araştırmada esnaflar arasındaki komşuluk ilişkileri değerlendirilmeye çalışılmaktadır. Özellikle "komşuluk algısı ve duygusu, komşuluk ilişkileri ve de komşuluk ilişkilerinin değişim ve dönüşümünü anlama ve yorumlamayı amaçlayan araştırma nitel bir şekilde gerçekleştirilmiştir. $\mathrm{Bu}$ minvalde Konya Bedesten Çarsısında yüz yüze görüşme tekniği kullanılarak hazırlanan açık uçlu 10 soru ile görüşmeler gerçekleştirilmiştir. Görüşmeden elde edilen veriler ses kayıt cihazı ile kaydedilmiş ve çözümlemeleri yapılmıştır. Araştırmanının evreni sadece Konya Bedesten Çarşısı ile sınırlıdır. Evren olarak bedesten çarşısının seçilmesinin nedeni bu çarşının köklü bir geçmişe sahip olması, eski ve yeni esnafların burada yoğun bir şekilde bulunması, işyerlerinin birbiri ile daha yakın mesafede bulunması, farklı sektörlerin burada yoğun bir şekilde bulunmasından dolayıdır. Örneklem olarak amaçsal örneklem seçilmiş olup özellikle farklı iş sektörleri, yaş, bedestende çalışma süresi gibi değişkenler baz alınarak 15 esnaf ile görüşmeler gerçekleştirilmiştir. Bazı eksen başlıklar etrafında bedestende komşuluk anlaşılmaya çalışılmıştır. Bu minvalde komşuluk algısı anlaşılmaya ve bir duygu olarak komşuluğun nasıl bir insani ilişki zeminine sahip olduğu sorgulanmıştır. Ardından komşuluğa ilişkin bir takım sosyal etkileşim pratikleri ve ritüelleri sorgulanmıştır. Özellikle geçmişten günümüze değişen ve dönüşen toplumsal yapı ve kültüre paralel olarak geleneksel esnaf kültürünün bedesten içinde yeni kuşakla birlikte nasıl değiştiği somut örnekler üzerinden anlatılmıştır. Öz itibariyle bedestenin ruhu, sosyal ilişkilerde kendini zaman zaman hatırlattığ görülmüş ancak gelişen yeni koşullarda direnme mekanizmalarını giderek yitirdiği tespit edilmiştir. Özellikle eski esnafların giderek sahneden çekilmesi yahut müdahil olduğunda yeni aktörler tarafindan uzak tutulması bir kırılmanın en canlı örneklerini ifade etmektedir. Toplumsal hayatın adeta mayasını elinde tutan bir mekan olarak Konya Bedesten çevresi, sahip olduğu kültürel izleklerle anlaşılması ve korunması gereken ören yeri gibidir. $\mathrm{Bu}$ çalışma bir etnografik inceleme düzeyinde mevcut durumun tespitine, yaşanan değişimin gerilim noktalarına, eski ile yeninin kıyas ve karşılaşma noktalarına temas etme amacindadır.

$\mathrm{Bu}$ çalışma Necmettin Erbakan Üniversitesi Rektörlüğü, Sosyal ve Beşeri Bilimler Araştırma ve Yayın Etiği Kurulu'nun 31/08/2020 tarihli 2020/67 numaralı karar sayısı ile etik kurul onayı almıştır.

\section{Esnaf Komșuluğu ve Toplumsal Yansımaları}

Çalışmanın bu bölümünde esnaf komşuluğu üzerine Konya Bedesten çarşısında yapılan görüşmeler sonucunda 3 ana başlık üzerine yoğunlaşılmıştır. Bu bağlamda komşuluk algisı ve duygusu, komşuluk ilişkileri ve de komşuluk ilişkilerinin değişim ve dönüşümü üzerinden araştırmanın nitel verileri yorumlanmıştır.

\subsection{Komşuluk Algısı ve Duygusu}

Araştırmanın bu bölümünde esnafların hem komşulukla ilgili hem de bedesten çarşısına dair algıları ve duyguları ele alınmaktadır. Mutluluk, sevinç, özlem, kızgınlık, kıskançlık gibi pek çok duygu esasen yaşanmış ya da yaşanıyor olanın bir dişa vurumudur. Bedesten çarşısı 
içerisindeki hayatların, tecrübelerin, anlamlandırmaların imgesi çok zaman bu duygulardır ve oradaki hayat ve düşünce, duygular vasitası ile ifade edilebilmektedir. Araştırmaya katılanların dükkan komşuluğunu nasıl ifade ettikleri, bu komşuluğun kendilerine neleri ve hangi duyguları hatırlattıkları gibi konularla birlikte bu çarşı içersinde kendilerini nasıl hissettikleri, dükkan komşularını ve bu çarşıyı ne düzeyde benimsedikleri gibi konular üzerinde durularak komșuluk algısı ve duygusu betimlenmeye çalışılmaktadır. $\mathrm{Bu}$ konu ile ilgili görüşmeden elde edilen bilgiler büyük oranda birbiri ile benzeşmektedir.

"Dükkân komşusu demek; dar gününde, yok gününde yardım eden demektir, birbirine yardımcı olan demektir. Mutlaka onun derdini dinlemek, elimizden gelen yardım neyse onu yapmak veya onun benim derdimi dinlemesinden mutlaka memnun oluruz. Mutlu oluyorum, ben rahat hissediyorum kendimi bu bedestende. Bedesten esnafi olmaktan dolayı mutluyum." (Ö.D, 52, Gida Sektörü).

"Ben buraya işe başladığımda babam dedi ki: "bak bir tarafinda Aziziye Camisi, bir tarafinda Kapu Camisi var. Namazını kl, ben senden başka bir şey istemiyorum" dedi. Buranın manevi, farkl bir havasl var. Memnunuz, Elhamdülillah.” (E.Y, 47, Kozmetik Sektörü).

"Şimdi bu yaştan sonra bir yere gidemeyiz. Evet burada oluruz. Bunların hepsi burada yetişme adamlar. Burada yetişen adam, burayı hiçbir zaman bırakamaz. Pazar günü dahi geliriz. Illa burayı göreceğiz. Burada bir nefes alacağız ve gideceğiz. Burada bir şey yapmamız şart değil. Memnunuz biz buradan. Bizim dostlarımız, arkadaşlarımız burada. (E.S, 57, Gıda Sektörü).

"Şimdi semtimiz çok güzel, çarşımız çok güzel. Aşă̆ yukarl 45 senedir buradayız biz. Şimdi üç oğlan bir babayız biz aynı dükkânda. Bizim zamanımızda fazla okul yoktu, ilkokul vardl sonra sanata giderdik. 25 sene bilfiil işçilik yaptık ustamıza, 17 sene de ortakçılık yaptık Kebapçı Şükrü'nün orada. Bizim buradan kopmamı biraz zor. Artık eskisi gibi olmasa da bizim yerimiz burasi. Biz bedesten esnafiyı. Burada bulunmaktan memnunuz. "(H.M., 72, Lokanta Işletmeciliği).

"Burada bizim 5-6 tane dibimizde komşu var. Samimi olduğumuz, muhabbetimizin olduğu komşular. Dükkân komşularımızla muhabbetimiz çok iyi, aramız çok iyi. Beraber yeriz içeriz, her maddi durumda da birbirimize destek oluruz. Çok iyi komşularımızla aramız. Arada sirada sorun olsa da hem çarşıdan hem de bu komşularımızdan memnunuz." (M.K. 62, Gıda Sektörü)

"Bana burada dükkanımı kapatıp başka bir yerde çalışma teklifi geldi ve buradan kazandiğımın neredeyse iki misli maaş vereceklerdi. Fakat ben para için buralardan gitmem. Kapu Camii civarında olmayı seviyorum. Essimi, dostumu burada ziyaret ediyorum." (Ö.B. 57, Elektrik malzemeleri).

"Komşu sevilir, özlenir. Bu çarşlyı da çok severim. Bilmiyorum yani ben tekrar dünyaya gelsem bu Konya'da böyle bir yerde olmak isterdim. Komşu bizim hemen yanımızdadır. Bir şey olsa ilk ulașacă̆ımız yer orasıdır. (M.T. 41, Aktar).

"Burada bir esnaf kültürü var. O esnaf kültürü de komşuluğu etkiliyor. Esnaf kültürü olanlarla gerçekten çok iyi komşuluk kuruluyor. O beni anllyor, ben onu. Benim buradaki komşularım eski komşularım. Yıllardır biz beraberiz. Birbirimizi severiz." (İ.A. 43, Giyim Sektörü).

"Burada bizim yakınımızda olan komşularımız var; daha doğrusu her yakınımızda olanla çok iyi komşuluk da kurmuyoruz aslında. Daha çok bizim bu çevrede eski komşularımız var. Onlarla daha iyi komşuluğumuz var. Aslında eski komşularımız olmasa burası çekilmez olur belki;o zaman sadece işimize bakarız. Biz onlarla iyi vakit geçiriyoruz. Ama bir de şu var: şimdi insanlar işlerine çok yoğunlaştı. Eskisi gibi de değil ama yine de ben mutluyum burada çalışmaktan”. (B.Y. 52, Kozmetik Sektörü).

"Eskiye oranla çok değil komşuluk. Bizim burada gene bir komşuluk var. Yani istenilen seviyede değil aslında ama burada yine yakın komşularımı var. 5-6 kişi. Onlarla iyi vakit geçiririz müşteri olmadığı zamanlarda. Bu çarşı eski. Yine bir samimiyet var eskilerde. Bir de hareketli burasi. Geleni gideni bol olur buranin. Eskisi kadar olmasa da mutluyuz biz burada." (M. S. 57, Giyim Sektörü).

Genel olarak bedesten çarşısında bulunan esnafların hem komşuları hem de çarşı ile ilgili düşünceleri benzeşmektedir. Çalışmaya katılanların tamamına yakını bu çarşıda bulunmaktan ve komşuluk ilişkilerinden kısmen de olsa memnundur. Burada bulunmaktan mutluluk duymaktadırlar. Bedesten çarşısı büyük ve köklü bir çarşıdır. Büyük ve köklü bir çarşı olmasına rağmen esnafların yoğun ilişki kurduğu esnaf sayısı 3-5 esnaf ile sınırlıdır. Esnafların komşuluk ilişkisi kurduğu esnaflar da genellikle ya çok yakınında -hemen bitişiğinde veya birkaç dükkân ötesinde- ya da çok eskiden beri burada bulunan ve belirli bir esnaflık kültürüne sahip olan komşulardır. Genel itibari ile komşuluk ilişkileri vardır; ancak bu komşuluk ilişkileri birkaç esnaf ile sınırlıdır. Yeni gelen diğer esnaf ya da daha uzak dükkanlar ile komşuluk ilişkisi zayıf görünmektedir.

Bunların dıșında komşuluk ilişkisinin bulunmadığını ya da oldukça az olduğunu söyleyen esnaflar da bulunmaktadır. Genel olarak diğer esnaflara göre bu esnaflar, bu konuya ilişkin daha fazla serzenişte bulunmaktadırlar.

"Ben aşağı yukarı 40 senedir buradayım. İşte Aziziye'nin orada, burada... Ben şimdi dişarlya kapanık, öyle herkesle kaynaş bir düzen tutan bir kişilik değilim. Çünkü o komşular yok. İşte bu seneler evvel vard. Ama șu 10-15 sene kim kimi kazlklasam, kim kimi ütsem, kim kimi ayağından çeksem derdinde. Yani ben bir hiçbir komşuluk görmüyorum şimdi. O yüzden de burada işin açıkçası çok mutlu da değilim. İşimizi yapma telaşındayız." (M.C. 71, Bakkaliye).

"Eski komşuluklar yok. Şimdi maalesef herkes, hep bana hep bana diyor. Ama bizde öyle bir şey yok. Selamlaşırız, merhabalaşırız. Yani, ama eski samimiyetler yok. Eskiden daha muhabbetliydi, daha bir 
ne bileyim daha bir güzeldi yani. Şimdiki gençler bilhassa hiç şey yok. Mesela ben bir Kenan Hacı Emmi'mi tanırdım Bedesten içinde. Rahmetli oldu. Uzun böyle fötr şapkall. Oğlum derdi; 'biz sabah gelir, dükkânı açarız, kapının önünü sularız, sandalyeyi koyarız kapının önüne, pidemizi söyleriz, çayımızı söyleriz. Yeriz içeriz. Bir müşteri geldi mi, siftah ettik mi içeri girerdik. Sandalyeyi alırdık. Yani bu elli sene öncesinin olayl. Ikkinci bir müşteri geldi mi dişarıya bakardık; dışarıda oturan var mı diye? Kardeş biz siftah ettik oraya git derdik. Ha baktık sandalye yok; ikinci satışı yapardık o zaman diyor.' Neticede eskisi kadar mutlu değiliz yani komşuluktan. Merhaba mı merhaba deriz." (H.G., 63, Giyim Sektörü).

Duyguların sözlü ya da sözsüz ifadesi çok zaman yaşanmışlıkların, toplumsallığın bir göstergesidir. $\mathrm{Bu}$ göstergenin sözlü ifadesi, sözsüz ifadesi, seçilen kelimeler ve bu kelimelerin ifade ediliş biçimi ve vurgusu toplumu anlamada birer donedir. Araştırmanın bu bölümünde esnaf komşuluğunun duygusal olarak tezahürleri değerlendirilmeye çalışılmıştır. Elde edilen verilere göre esnaflar arasında büyük oranda komşuluk ilişkisi bulunmaktadır. Ancak bu komşuluk ilişkileri eski komşuluk ilişkileri kadar samimi, özverili değildir. Eski komşuluk ilişkileri gibi komşuluk yaşanmadığı için bu durumdan mutsuzluğunu belirten esnaflarla birlikte o çarşıda bulunmuş olmaktan ve sınırlı da olsa yaşanılan komşuluk ilişkilerinden mutlu olan esnaflar da bulunmaktadır. Ancak komşuluk ilişkileri açısından geçmişe dair yoğun bir özlem söz konusudur.

\subsection{Komşuluk İlişkileri}

Araştırmanın bu bölümünde Konya Bedesten Çarşısı esnafının komşuluk ilişkileri ele alınmaktadır. Komşuluk ilişkileri paylaşma, dayanışma, yardımlaşma, sosyalleşme, sosyal kontrol ve komşuluk hukuku çerçevesinde gerçekleşen sosyal bir olgudur. Bu eksende araştırmanın bu bölümünde dükkân komşularına "1- Komşular arasında iş, çevre ve diğer iş dışı konular ile ilgili bir yardımlaşma, paylaşma ve dayanışma görülür mü? 2- Komşularınız ile karşılıklı ziyaretleşme gerçekleşir mi? 3- Komşularınızla iş yerinde veya iş dişında aktiviteler yapar mısınız? 4Komşuluk ilişkilerinde beğendiğiniz ve beğenmediğiniz durumlar nelerdir? Komşularınız ile olumsuz bir durum yaşandığı zaman nasıl çözüm bulunur? Dükkân komşularınızla sizin ahlaki, kültürel, insani, iş ahlakı ile ilgili değerleriniz örtüşür mü? 5- Bir komşuluk hukukundan bahsedilebilir mi?" soruları eşliğinde meseleye ilişkin katılımcıların görüşleri ele alınmaya çalışılmaktadır.

Yardımlaşma, dayanıșma ve paylaşma komşuluk ilişkilerinin en fazla görünen yüzlerinden biridir. Komşuluk denince çok zaman ilk akla gelen taraflardan biri budur. $\mathrm{Bu}$ minvalde esnaflar arasında komşulukların yardımlaşma, paylaşma ve dayanışma ekseninde farklı değerlendirmeleri bulunmaktadır.

"Bizde özellikle işimiz olduğu zaman aynı işi yapan komşularımızdan bir yardım isteme oluyor. $\dot{I}_{S}$ yerlerimizi birbirimize emanet edebiliyoruz. Mesela komşu namaza gidiyor, ben namaza gidiyorum, aynı işi yaptığımız komşularla fiyatları biliyoruz mesela. Kaça aldığımızı verdiğimizi bildiğimiz için satıyoruz mesela.
Ama bunun içerisinde hala bir şey var yani, ne diyeyim kıskançlık mı diyeyim rekabet var yani." (E.Y, 47, Kozmetik Sektörü).

"Yani ister istemez herkesin durumuna göre bazen borçlanma oluyor. Ben şimdiye kadar hiç almadım Allah'a şükür. Ama gitsem istesem verir mi? Verirler. Onlar istese biz de verir miyiz? Veririz. İş görmek, insanın sikıntısinı gidermek iyidir yani. "Allah razı olsun sıkıntımı giderdi" demesi ne kadar güzel bir şey. Zaman zaman komşuların bu ihtiyaçlarını paylaştığımız olur.” (Ö.D, 52, Gıda Sektörü).

“Şunu söyleyeyim: mesela ben Eyüp'ü tanırım, para lazım olduğunda gelir isterim. Mevlüt'ü tanırım, arkadaki komşuyu tanırız. İhtiyaç olduğu zaman gider isteriz ama onu gününde iade etmek lazım. Gününde iade edemezsen, bunu ona söylersin "ya ben denkleştiremedim bana iki gün daha müsaade et" diye. (H.M., 72, Lokanta Işsletmeciliği)

"Geçmişten kalma komşularla ilişkilerimiz çok güzeldir. Şimdi mesela benim burada iki komşum var, öğlen yemek yeriz, çay içeriz, muhabbet ederiz, ama üçüncü kişi yok, eskisi gibi komşu yok." (Ö.B. 57, Elektrik Malzemeleri).

"Yani son iki seneye kadar ilişkilerimiz daha yoğundu. Mesela, birlikte pikniğe falan giderdik. Bizim kebapçı yemek falan yapardl, güzel tirit yapardl. Şimdi artık, tabi insanların çocuğu büyüdü, evlendi, telaşesi çoğaldl. Biraz da ondan olabilir. Geçmişteki gibi olmuyor." (M. S. 57, Giyim Sektörü) .

"Yeni esnafların hiçbiri de bu caddede kimler var, kimler oturuyor bilmez. Biz hala meraklıyı, bakarız kimler geldi kimler geçti diye. Güvenliği eskiden esnaf kendisi sağlardı. Bir tırnakçı falan görsek çevremize haber verirdik. Şimdi bakıyoruz üç beş kişi saylyoruz. Kime haber vereceğiz? Geri kalanların hepsi yeni. Hiç komşuluk ilişkisi yok, arkadaşlık ilişkisi yok. Tamamen bitti. Esnaftan bu kültür kalktı.” (E.S, 57, Gıda Sektörü).

"Burada güvenlikle ilgili bir şey olduğunda komşulara haber ederiz. Haber edebildiğimiz kadar ederiz. Ama tabi bu da yakın çevremize oluyor tabi. Yani şu ara, güven timleri falan var. Onların baya bir faydasın gördük biz.” (M. S. 57, Giyim Sektörü) .

Bedesten çarşısındaki esnaflar arasındaki komşuluk ilişkileri eskiden beri süregelmektedir. Ancak ilişkilerin göstergelerinden biri olan paylaşma olgusunun zayıfladığı da görülmektedir. Daha çok en yakınındaki komşularla veya eskiden ilişkisi olduğu komşularla paylaşma devam etmektedir. Özellikle birbirinden borç para alma, iş yerini emanet etme, işlerin yoğunluğunda yardım etme, ortaklaşa öğle yemeği gibi faaliyetler, güvenlik konusunda tedbirler kısmen de olsa yerine getirilmektedir. Ancak bu şekilde ilişkide olunan komşu sayısı oldukça sınırlıdır. Genel olarak esnaflar, komşuluk ilişkilerinde bedesten çarşısında eski komşuları ile daha yakın ilişkiler kurarken, yeni gelen esnaflar ile çok sınırlı bir komşuluk ilişkisi kurmaktadır. Şu da belirtilmelidir ki ilişkilerde gün geçtikçe daha fazla azalmanın olduğu görülmektedir. 
Komșuluk ilișkisinin yine en önemli göstergelerinden biri de karşılıklı ziyaretler ve ortaklaşa yapılan faaliyetlerdir. Bedesten çarşısındaki esnaflar arasında da bu tür ilişkiler vardır. Ancak paylaşma ve dayanışma olgusunda olduğu gibi bu tür faaliyetlerin yapıldığı esnaf sayısı oldukça sinirlidir.

\begin{abstract}
"Her Pazar ya da 15 günde bir 9 kişilik komşumuz olan arkadaşlarımız var. Mesela biz pazar günleri Sadri abi ve birkaç kişi toplanıp bir iki araba oluruz. Herkes düğün davetiyelerini getirir; hangisinin pilavi iyi ona gideriz. Yeri gelir üç pilava giderdik sabah saat 8.00'de buluşurduk. Ardında da gelir pazar günleri de dükkanımızda işin başına geçerdik. Bunu bazen yapıyoruz ama eski heyecanlar da kalmadl. Azaldı böyle beraberce gezmelerimiz. Yine bedestenden arkadaşlarla toplanır halı saha maçı yapardık. O da azaldı" (M.T. 41, Aktar).
\end{abstract}

"Şimdi bizim toptancılık zamanında orada mesela iyi komşularımız vardl. Ramazanlarda birbirimize gider gelirdik, iftar açardık, muhabbet yapardık. Aramızda mesela para toplardık, havuz biriktirip ortak ticaret yapardik. Gidişimiz gelişimiz mesela öyleydi. Bayramdan sonra birbirimizin dükkanlarına bayramlaşmaya giderdik. Şimdi maalesef bayramdan sonra herkes dükkanında normal günmüş gibi devam ediyor" (Ö.D, 52, Gida Sektörü).

"Biz sabah kahvaltısı hazırlardık, karşımızdaki sağımızdaki solumuzdaki komşularl davet ederdik. Cumartesi günü bilhassa güveç pişirirdik toprak tencerede, Konya'mızın eski etlekmeğini yapardık. Komşularımızın hepsini çă̆ırırdık ikram ederdik. Bayramlarda birbirimizin evine ziyarete giderdik. Bayram dönüşü hemen komşularımızın yine işyerlerini ziyaret ederdik. Bayramlaşırdık. Ama sevgi vardı, saygı vardl. Şimdi onlar yok.” (E.S, 57, Gıda Sektörü).

“Komşularımızla ortaklaşa bir şeyler yapardık eskiden. Burada bir salata yapardık; komşularl, yoldan geçeni çağırırdık. Beraberce yer içerdik. Onlar da mutlu olurdu, bizde. Benim dediğim 90’lar... “(B.Y. 52, Kozmetik Sektörü).

"Valla eski düğünler yok. Eskiden bahçelerde pilav pişirilirdi, komşular sabaha kadar beklerdi. Şimdi o kültür yok ama gidilir. Eskisi gibi samimi ilişkiler bitti desek yeridir.” (E.S, 57, Gıda Sektörü).

“Az önce bir dükkân komşumla bu konular üzerine sohbet ettik. Evimizden daha çok dükkânda vakit geçirmekteyiz. Bu bakımdan dükkân komşuluğu önemlidir. Komşuluk ilişkisi olarak şunları anlatayım, bu sokağın eski esnaflarını biliyorum babamdan dolayı. Babamların zamanında burada çok sıkı komşuluk ilişkileri vardl. Samimi ilişkileri vardl, birlikte şehir dışlarına da giderlerdi. Biz 4, 5 arkadaş olarak babamgilden kalma bu sıkı komşuluk ilişkilerini devam ettiriyoruz. Her gün sabah namazından sonra erkenden dükkâna geliriz bir, bir buçuk saat mutlaka konuşuruz burada 3-4 komşumla bunu yaparı. Zaman zaman onlarla da iş dişında beraberce ziyaretler, gezmeler falan yaparı.." (S.B., 60, Giyim Sektörü.
"Bizim eskiden komşularımızla aramız çok iyi idi. Birbirimize her şeyi danışır, görüşürdük. Birisinin hayırl bir işi var; danışırd. Problemleri beraber çözerdik. Düğünü, derneği beraber yapardık. Şimdi gençler kendi evleniyor, kendi düğ̈̈nünü yapıyor, kendi boşanıyor" (M.C. 71, Bakkaliye).

Komşuluk ilişkilerini anlamanın en önemli yollarından biri de ziyaretleşme ve ortaklaşa yapılan işlerdir. Görüşme yapılanların tamamı komşuluk ilişkilerinde birbirini ziyaret ettiklerini ve ortaklaşa bir faaliyet yaptıklarını belirtmişlerdir. Komşular arasında ziyaretleşme ritüelleri iş yerinde karşılıklı ziyaretleşme, bayram ziyaretleri, düğün, taziye veya asker uğurlama ziyaretleri biçiminde gerçekleşmektedir. Ortaklaşa yapılan faaliyetler en fazla yapılanı genellikle iş yerinde ortaklaşa yapılan öğle yemekleri veya bir iş yerinde hazırlanan yemek sonucunda komşuları davet etmektir. Bunun dişında beraberce yapılan piknikler, geziler, halı saha maçları gibi komşuluk ilişkisinin pekiştirilmesine yönelik faaliyetler yapılmaktadır. Ancak yapılan görüşmelerde katılımcılar bu tür faaliyetleri anlatırken çok zaman nostalji anlatımı haleti ruhiyesine bürünmüşlerdir. Genellikle eski komşuluk ilişkilerine dem vurup bugün büyük oranda ziyaretleşme ve ortaklaşa iş yapma faaliyetlerinin azaldığından bahsetmişlerdir. Ancak kısmen de az da küçük gruplar itibar ile komşular arası ziyaretleşme ve ortaklaşa yapılan faaliyetler devam etmektedir.

Yine komşuluk ilişkilerinin en önemli göstergelerinden biri de birbirleri ile yaşanan olumlu ve olumsuz durumlardır. Özellikle komşuluk hukuku çerçevesinde olumsuz durumlarda, resmi ya da gayri resmi şekilde çözüm yollarının nasıl gerçekleştiği bu bölümde değerlendirilmektedir.

"Burada bazen tartışmalar çıkar. Özellikle yer kavgalarl olur. Sen bunu niye buraya koydun, yeri işgal ettin diye tartışmalar çıkar. En fazla bu görülür.” (M.C. 71, Bakkaliye).

"Komşuluk içerisinde ister istemez oluyor. Devamlı sık olmaz da... Ramazanlar'da çok olur mesela. Ya ufak bir şeyden, kıvılcımdan iki komşu birbirine girebilir. Bu şudur mesela benim işim bu iş ya farklı bir sektörle kavga olmaz benim. Aynı sektördekilerle, karşılıklı yanyana kişiyse olur yani. Adam mesela yazmıştır üzerine bir fiyat, ya da bir fiyattan veriyordur, müşteriden duymuştur o fiyatı mesela. 15 lirayı duymuştur 12'den veriyim der mesela. Burada mesele mal satmak değil, beni rencide etmek baltalamak yani. Bunlar oluyor ama uzun sürmüyor. Bir şekilde komşular araya giriyor. Mesela ben birkaç kere dükkânı bıraktım gittim. Yüz yüze bakıyoruz. Aynı sokağın içindeyiz. Bazen de yer tartışmalar oluyor. Ancak Belediye Zabitalarl çizgi çekti, iki tane. Önce beyaz çizgiyi sonra sarlyı çektiler. Ya şöyle olur, hani köşelerde daha fazla çıktığ zaman yan taraftaki gözükmez mesela ister istemez uyarır." (E.Y, 47, Kozmetik Sektörü).

"Yani ister istemez oluyor. Bizim burada şerli bir insan yok. Görmedik, ama ă̆ız dalaşı olmuş mudur? Olmuştur. Kapı önünde cephesini kapattı diye lüzumsuz sebeplerden bazen atışma olmuştur yani." (Ö.D, 52, Gıda Sektörü). 
"Ahlak da değişti. Mesela şimdi adam şurada iş yapıyor. Maşallah tebarekallah ne güzel işi var demiyor. Fesatllk var. Çekememezlik var." (E.S, 57, Gıda Sektörü).

"Bu sokak, değişik bir sokak. Biz burada birbirimize saygilıyı, burada ahlak dişı davrananları sokak kendiliğinden atmaktadır, bir bahane oluyor kendiliğinden gidiyor. Dükkân bir emanet yeridir. Bir sanayiciye, o ortama uygun müşteri gelir ve orada ortama uygun bir şekilde alışveriş yapılır. Bizim burada ise yeri geldiğinde çocuk eğittiğimiz zamanlar da olur, o yüzden burada da bizim işimizin fitratına yönelik bir alışveriş durumu vardır. Kadınlar için aileler için daha uyumlu bir ortam vardır burada." (S.B., 60, Giyim Sektörü).

"Komşu komşunun külüne muhtaçtır derken mesela şimdi komşu dışarıya malını koyuyor. O koyduğu mal senin ticaretine olumsuz etki yapıyorsa müdahale edeceksin. O mall oradan çekecek. Kendi menfaati malı oraya koyuyor. Sana gelip danısmıyor. Komşum şu benim. Bu mall buraya koyarsam ona zarar verir miyim diye düşünmüyor. Herkesin hakkını, hukukunu iyi bilmesi gerek.” (B.Y. 52, Kozmetik Sektörü).

Komşu esnaflar arasında yer işgaliye tartışmaları, ürünlerin cephesini kapatma tartışmaları, aynı ürünlere dair fiyat tartışmaları, çekememezlik gibi olumsuz durumlara dair bazen tartışmaların ortaya çıktığı görülmektedir. Ancak bu tartışmalar büyük çoğunlukla ya benzer meslek dalları arasında olanlarda ya da çarşıya yeni gelen diğer esnaflarla yaşanmaktadır. Şunu da belirtmek gerekir ki bedesten çarşısında genel bir esnaf ahlakından, iş ahlakından bahsedilebilir. Özellikle yeni gelen kuşaklarla ve genel olarak esnafların çoğunda maddi düşüncelerin son zamanlarda daha ön plana çıkması ile kısmen de olsa bu esnaf ahlakının azaldığı düşünülmektedir.

Komşu esnaflarda yaşanılan olumsuz durumlar bazen resmi kanallar aracılığı ile çözümlenebilirken bazen de gayri resmi bir şekilde, kendi diğer komşularının yardımı ile çözümlenebilmektedir. Özellikle çevrede bulunan eski ve yaşça büyük komşuların esnaflar arasındaki olumsuz durumların çözümlenmesinde önemli bir rolü bulunmaktadır.

“Bazen Ramazan'larda incir kabuğunu doldurmayacak şeylerden dolayı ăgzımızın tadının kaçtığ oluyor ama işte bir saat sonra kusura bakma deniyor, özür dileniyor, o iş bitiyor.” (Ö.D, 52, Gıda Sektörü).

'Eskiden bilmezdik polis falan. 155' $i$ de bilmezdik. Oradan bir amca çıkardı uyarırdı; arayı bulurdu. Şimdi kimsenin önemsediği yok. Şimdikiler uyaranlara "sen karışma, işine bak” diyor. O zaman sen karışır misın? Geçenlerde kâğıt toplayan çocuklar burada tartışıyordu. Arkadaşlar dövüşmeyin, bölüşün dedim. Bana "sen işine bak" dedi. Bir şey olsa artık polise haber ederiz galiba." (B.Y. 52, Kozmetik Sektörü).

“Eskiden mesela bir büyüğün yanına gidilirmiş, bu boş ver tartışmayı düğ̈̈n dernek işlerini ufak da olsa bir akıl alınırmış. Şimdi herkes akıllı olmuş. Çok az yani artık.” (E.Y, 47, Kozmetik Sektörü).
"Burada az da olsa bazen tartışmalar yaşandl. Biz araya gireriz böyle bir durum olunca. Başka komşular araya girer, çözeriz. Nadir de olsa polisin geldiği tartışmalar oldu.” (M.K. 62, Gıda Sektörü).

"Buralarda bir problem olduğu zaman artık polis aranır. Araya girenler oluyor ama onlara da "sen karışma" diyorlar. O yüzden araya girme, problemi çözme azaldı. Yeni esnaflar çok ters davranıyor. Aslında bizim de ă̆ırımıza gidiyor ama. (M. S. 57, Giyim Sektörü).

Geleneksel kültürün hâkim olduğu yerlerde çok zaman ilişkileri düzenleyen mekanizmalardan birisi de kanaat önderleridir. Kanaat önderleri oradaki insanların kimi problemlerinde çözüm bulan, yardımlaşmayı, dayanışmayı, örgütlenmeyi, belirli adabı muaşeret kurallarının yerleşmesini sağlayan, aracılık rolü üstlenen kişilerdir. Ancak günümüzde modernleşmenin etkisi ile birlikte insanların kanaatlerini şekillendiren başka mekanizmalar orta çıkmıştır. Özellikle bireysel yaşamın çok daha ön plana çıkması ile birlikte kanaat önderlerinin bu alandaki rolünün azalmasını toplumun birçok yapısında görebilmek mümkündür. Esnaf komşuları arasında özelde yaşanan problemlerde; genelde birçok aktivitede kanaat önderlerinin rolü azalmıştır. Araştırmaya katılan esnafların büyük çoğunluğu yaşanan problemlerde artık resmi yapıların devreye girdiğini ifade etmektedirler. Zaman zaman çarşı esnafinın devreye girerek problemlerin çözümünde destek olduğunu söyleseler de bu durumun azaldığını söyleyebilmek de mümkündür.

\subsection{Komşuluk İlișkilerinin Değișim ve Dönüşümü}

Toplumsal alan her geçen gün değişim ve dönüşüm içerisinde bulunabilmektedir. Bu değişim kimi zaman olumlu yönde gerçekleşirken kimi zaman da olumsuz bir yönde gerçekleşebilmektedir. Yaşanılan değişimden, etkileşim içerisinde bulunan toplumun etkilenmesi neredeyse imkânsız gibidir. $\mathrm{Bu}$ minvalde komşuluk ilişkileri de son dönemde hızla değişmeye başlamıştır. Araştırmanın bu bölümünde esnaf komşuluğu özelinde "Dükkân komşuluğunun şu anki durumu ve geleceği hakkında ne düşünürsünüz? Komşuluk ilişkileri değişti ise ne gibi etkenler komşuluğun değişmesinde etkili oldu? 2. veya 3. kuşak dükkân komşuları ile ilişkileriniz nasıl?" şeklindeki sorular eşliğinde komşuluk kültürü ile ilgili bir değişim durumunun varlığı ve niteliği değerlendirilmektedir.

"Şimdi ben 15-16 yıldır buradayım. Ama benim çıraklık, çocukluk zamanımdaki komşuluklarla şimdiki komşulukları ölçecek olursak çok fark var yani. Daha önceki yıllara, büyüklerimizin yaptı̆̆ına bakacak olursak komşuluk diyalogları çok daha farkll." (E.Y, 47, Kozmetik Sektörü).

"Şimdi aşağı yukarı ben 45 senedir Bedesten içindeyim zaten. Yani Bedesten içinde yetiştik. Ama tabi şimdi eskiden komşuluklar daha bir değişikti. Sabah herkes mesela Kapu Camisi'ne gelirdi namazını kılardı, erkenden dükkanını açardı. Ondan sonra kapının önleri temizlenirdi, sulanırdı. Sabah komşulara bir kahvaltı verilirdi, çağırılırdı sağdan soldan. Yani biz öyle gördük, gördüğ̈̈mü anlatıyorum, yaşadı̆̆ımı 
anlatıyorum. Ama şimdi maalesef şurada şu caddenin üzerinde birkaç tane komşumuz var, samimiyiz, diğerleriyle değil.” (H.M., 72, Lokanta Işsletmeciliği).

"Şimdi sabah erken geliyoruz, güya erken 8'de. Eskiden dükkanlar altı buçuk yedide açılırdı. Kapının önü süpürülür, temizlenir. Ama şimdi yok. Hele yeni nesilde hiçbir şey yok. Millet dükkândan içeri girdi mi komşusunu kimse bilmiyor. Yani ne yer ne içer nerede oturur bilmiyoruz. Eskiden şu caddesinin başından sonuna kadar hangi esnafin mahallesi neresi, evi nerede, oturduğu sokağa kadar bilinirdi." (E.S, 57, Gıda Sektörü).

Burada benim yaş gruplarım var; bir de gençler var. Şu anda dostluk vesaire değil de menfaat ilişkileri var. Bizim zamanımızda dostlarımız, eski arkadaşlarımı bir şey oldu mu birbirimize maddi manevi yardım ederdik, hani kötü yola gidiyorsa onu çamurdan çekip çıkarırdık, ama şimdi öyle değil, çamura düşen insanın elinden tuttun mu o kendisi ile birlikte seni de çamura batırıyor. Her şey değişti, maneviyatta değişti. (Ö.B. 57, Elektrik Malzemeleri).

Hemen hemen esnafların tamamına yakını komşuluk ilişkilerinin eskisi kadar sağlam zeminlerde ilerlemediğini dile getirmektedirler. Zaman zaman geçmişi yad etme, nostalji ihtiyacı gibi daha çok duygusal tepkiler, insanların geçmişe özlem duymalarına neden olabilmektedir. Böyle bir durumun günümüz değerlendirmelerinde komşuluk ilişkilerine dair etkisi kaçınılmazdır. Ancak görünen değişimler üzerinden yapılan değerlendirmeler komşuluk ilişkilerinin azaldığını da göstermektedir. Ayrıca genel olarak değerlendirmelerde yeni kuşak esnafların, esnaflık kültüründen uzaklaştığı da dile getirilmektedir. Bununla birlikte görüşme yapılan kişilere göre, hem kendi iş yapış şekillerinde meydana gelen değişimler hem de daha çok yeni kuşak esnaflarla ilgili olarak ortaya çıkan "esnaf kültüründen uzaklaşma" komşuluk ilişkilerinin değişimine olumsuz manada etkide bulunmaktadır.

"Kapitalizmin verdiği bir şey sanırım. Madde mananın önüne çılkyor. İnsanlar kendi kendine yetmeye başlayınca, lüks biraz daha farklı dünya görüşleri değişiyor gibi geliyor. Eskiden insanlar biriyle dayanışma içinde olurdu. Dayanma ihtiyacı hissederdi. Ceplerindekini paylaşırlardl. Şimdi öyle değil. Rekabet yapıyor mesela, komşu zarar etmesin diye zarar ediyor. Ben öyle söylerim. Rekabetin adını öyle söylerim. Rekabetin adını komşu zarar etmesin diye zarar etmek..." Şimdi bir de gençler de farklı davranıyor. Gençler ticarete ufak çıraklıktan başlayacak, ahlaki değerleri ögrenecek, mesleki ilkeleri ögrrenecek, aşama aşama kalfa olacak usta olacak. o Osmanlının döneminde, Selçuklunun dönemindeki ahilik sistemi olursa o zaman esnaflı̆̆ın da değeri olur. (M. S. 57, Giyim Sektörü).

\footnotetext{
"Esnafllk çekirdekten olur. Çekirdekten esnaf olmazsan, mümkün değil işletemezsin. Bugünlerde, virüsün yaygın olduğu günlerde meşhur bir şey var. Sosyal mesafe diyorlar. Aslında yanlış kullaniyorlar bunu. O dedikleri bence "fiziki mesafe". Şimdi bizim yeni kuşakla "fiziki mesafemiz" az da "sosyal mesafemiz" fazla. Bizim
}

aslında birbirimiz arasında daha fazla sosyal olmamız lazım.” (B.Y. 52, Kozmetik Sektörü).

"Ticari para kazanma daha önemli hale geldi. Eskiden maneviyat ön plandayd, maddiyat ikinci plandaydl, para pul önemli değildi, insanlık olsun yeterliydi. Öyle düşünürdük. Biz hala öyle düşünüyoruz ama şu anda paran varsa en iyi sensin, maddi yönden iyisin ya tamam zirvede olan sensin. Eskiden de zenginler vard ama zenginim diye böbürlenmezlerdi, sonradan görme değillerdi. Anneden babadan gören insanlardi. Mesela yıllardır zengin olan komşularımı var. Onlar gibi zenginlerle eski zamanlarda stralarımı olurdu, büyüklerimiz bizler için bir şeyler yaparlard o zamanlar. Yemek yeme siralarımız olurdu." (Ö.B. 57, Elektrik Malzemeleri).

"Şimdiki gençler esnaflık işinde pek eğitilemiyorlar. Birinci derecede sosyal medya yetiştiriyor; öncesinde televizyon etkiliydi. Aile geri plana düştü. Artık yakınlar uzak, uzaklar yakın oldu, çocuklarımızdan haberimiz yok. Çocuklarımızı bilgisayar, okul, arkadaş eğitiyor. $\dot{I}_{S}$ yerinde eğitilmiyorlar.” (S.B., 60, Giyim Sektörü).

"Benim çocuğum benim tanıdıklarımı tanırsa tanır onun dışında yok. Geliştirmiyorlar kendilerini. Komşuluk yok. Önlerinde telefon, bilgisayar. Hayatlart o. Mesela bu adam namazdan geldi şimdi yarım saat bir saat otururuz, kaynatırız. Ondan sonra dağılırız. Yarım saat sonra denk gelirsek bir daha otururuz. Bir de yanımda çalışan beni beğenmiyor, gidip dükkân açıyor. Adam şimdi beş sene durmuyor gidiyor dükkân açıyor. İşi belledim, sanatı belledim diyor. Ondan sonra bakıyorsun battı. İs yapamadı. Şimdi her yer kapalı dükkân. Bu adamlar nereden geldi nereye gitti. Ortalarda yok. Tekrar aslına dönüyor. Birinin yanında çalışmaya başlıyor." (Ö.D, 52, Gıda Sektörü).

"Eskiden tatil falan bilmezdik biz. Adam şimdi kafast esti mi ben gidiyorum tatile diyor. Eskiden küçük yaşlarda alır, eğitirdik. Gençler küçük artık küçük yaşlarda eğitilmediği için bu kültürü alamıyor." (H.M., 72, Lokanta Işletmeciliği).

"Şimdi çalışma yaşı çok yükseldi. 18 yaşından sonra çırak olamaz kimse. Bu senin oğlun, kızın da olsa öyle. Geçenlerde sattığ ürün 25 Tl.50 kuruş tutmuş. Baktım müşteriden 50 kuruş istiyor. Uygun bir dille anlatmaya çalıştım uygun olmadığını.” (E.B., 50, Gıda Sektörü).

Konya Bedesten Çarşısında komşuluk ilişkilerinde bir değişimin gerçekleştiği açıkça görülmektedir. Özellikle daha önceki yıllara göre bariz bir değişimin var olduğu katılımcılar tarafından çoğunlukla zikredilmektedir. $\mathrm{Bu}$ değişimin ortaya çıkmasında etkili olan faktörlerin başında kişiler arası iletişimin değişen boyutu gelmektedir. Kişiler arası iletişimde maddi unsurlar daha ön plana çıkmaya başlamıştır. Samimiyetler azalmış, sadece çok küçük komşu esnaf grupları içerisine hapsolmuştur. Küçük esnaf grupları da büyük çoğunlukla eski ilişkileri devam ettirmeye çalışan komşulardır. Bu komşuluklarda bile bir zayıflamanın var olduğu gözlemlenmektedir. Ayrıca çarşı içerisinde köklü esnafların yavaş yavaş işlerini başka işletmelere devretmesi, çocuklarına bırakması sonucunda yeni komşuluk ilişkileri kurmak zorunlu hale gelmiştir. $\mathrm{Bu}$ komşuluklarda 
genellikle daha genç nesil ile iletişim biraz daha zor hale de gelmiştir. Özellikle belirli bir esnaf kültürü edinmeyen yeni nesil esnaflar ile hem genç ve yeni esnaflar hem de eski esnaflar problem yaşayabilmektedir. Yine özellikle genç nesil esnafların esnaf kültüründen uzaklaştığına dair düşünceler hakimdir. Modernleşme ile birlikte komşuluk kültürünün azaldığı dile getirilmektedir.

\section{Sonuc}

Komşuluk toplumsal hayatın en önemli bileşenlerinden, görünümlerinden biridir. Özellikle geleneksel ilişkilerin yoğun olduğu toplumsal yapılarda daha yoğun bir şekilde görülmektedir. Ancak günümüzde farklı nedenlerden dolayı komşuluk ilişkilerinde değişimin olduğu gözlenmektedir. Komşuluk denilince akla ilk mahalle, sokak, apartman komşuluğu gelmektedir. Fakat komşuluk mekân bağlamında daha geniş bir alana tekabül etmektedir. Bu komşuluk alanlarından biride iş yeri komşuluğudur. Bir iş yeri başka bir iş yerine büyük ihtimalle komşudur. $\mathrm{Bu}$ komşuluk AVM'deki işyerlerinde, sanayi sitelerinde, organize sanayi bölgelerinde, çarşıda veya bedestende görülebilmektedir. Bu çalışmada da köklü bir geçmişe sahip bedesten esnafı üzerinden komşuluk ilişkileri irdelenmektedir. Bedesten çarşısında böyle bir araştırma yapmanın nedeni, hem yıllardır bu mekânda iş yapan esnafların daha yoğun bulunması hem de daha yeni nesil iş yerlerinin bulunmasıdır. $\mathrm{Bu}$ minvalde bedesten çarşısı eskiye dayanan ilişkilerin değişim ve dönüşümünü, yeni nesil işletmelerin komşuluk ilişkilerini görebilme e kıyaslayabilme adına önemli bir mekandır. Bu çalışmada, özellikle "komşuluk algısı ve duygusu, komşuluk ilişkileri ve de komşuluk ilişkilerinin değişim ve dönüşümü" alt başlıklarında nitel bir araştırma yöntemi olan görüşme tekniği kullanılarak esnaf komşuluğunun bir değerlendirmesi yapılmıştır.

Esnaf komşuluğunu görebilmenin en önemli araçlarından biri komşuluğa dair algılar ve duygulardır. Konya Bedesten Çarşısında esnafların komşuluk ile algıları birbirleri ile benzerlik göstermektedir. Bedesten çarşısı köklü bir çarşıdır ve esnaflar arasında bir komşuluk kültüründen bahsedilebilmektedir. Bu komşuluk kültürü son zamanlarda azalsa da buradaki eski esnaflar tarafindan yürütülmeye çalışılmaktadır. Paylaşma, dayanışma, yardımlaşma, güvenlik gibi pek çok konuda esnaflık kültürü gereği komşuluk ilişkileri devam edebilmektedir. Ancak burada görülen önemli noktalardan birisi bu ilişkileri devam ettiren komşu sayısının oldukça azalmasıdır. Daha önceleri çarşı esnafi büyük çoğunlukla irtibatlı iken, bugün komşuluk ilişkileri çok daha küçük esnaf grubu arasında geçmektedir. Komşuluk ilişkileri daha küçük, daha izole esnaf grupları arasında geçmektedir. Bu bakımdan esnaf komşuluğu ile algı komşuluk kültürünün var olduğu ancak son zamanlarda bu kültürün daha eski esnaf grupları arasında geçtiğidir.

Komşuluk ile algının en önemli görünümlerinden biri de komşuluğa karşı ortaya çıkan duygulardır. Duygular sadece bireysel alanın değil, toplumsal alanın da bir yansıması olabilmektedir. Bu bağlamda esnaflar hem bu çarşıdan hem de komşuluk ilişsilerinden mutluluk duymaktadırlar. Ancak son zamanlarda komşuluk kültürünün, iletişime geçilen komşu sayısının ve de komşular arasında ortak duygu ve düşüncelerin azalması komşuluğa karşı eskiye dair bir özlem duygusunun çıkmasına neden olmaktadır. Belki eskiye özlem duygusunun bir nostalji ihtiyacından ortaya çıktığı düşünülebilir. Ancak komşuların tamamına yakını, verdikleri somut örneklerle nostaljinin ötesinde komşuluk kültürünün olumsuz manada değişimine vurgu yapmaktadırlar.

Komşuluk kendi mekansal sınırlarının dahilinde ve haricinde ilişkisel bir ortaklık kurma biçimidir. Komşuluk bir mekân dahilinde geçmektedir ve bu mekânın ortak kullanımı yönünde belirli avantaj ve dezavantajları bünyesinde barındırabilmektedir. Bu bağlamda avantaj ve dezavantajları görebilmenin en iyi yollarından biri komşuluk ilişkilerini anlamaktır. Komşuluk ilişkileri paylaşma, dayanışma, yardımlaşma, ortaklaşa kullanım ve sosyal kontrol üzerine kurulu bir yapıdır. Bu yapı içerisinde zaman zaman yardımlaşma, dayanışma, paylaşma noktasında güzel şeyler yaşanırken özelikle ortaklaşa kullanım noktasında problemler yaşanabilmektedir. Ancak son zamanlarda belki modernleşmenin etkisi ile belki de başka diğer etkenlerle komşular arasında komşuluk ilişkilerinin daha yüzeysel bir zemine oturduğu, değiştiği ve dönüştüğü gözlemlenmektedir.

Görüssmelerden elde edilen verilere komşuluk ilişkileri değişim ve dönüşüm halindedir. Komşuluk ilişkilerinin, kültürünün edinimindeki en önemli araçlardan biri sosyalleşmedir. Özellikle son dönemlerde yeni kuşakların bu sosyalleşme süreçlerinden biraz uzak kaldığ 1 düşünülmektedir. Böylelikle belirli bir esnaflık kültürü edinmeden iş yapma süreçlerine dahil olanlarla komşuluk ilişkilerinin zayıf bir şekilde geçtiği dile getirilmektedir. Komşuluklar devam etse de daha yüzeysel, daha pragmatist, sı̆̆ bir düzlemde ilerlemektedir. Bu yüzden aslında hem yeni kuşak işletmeler hem de eski kuşak işletmeler komşuluk ilişkilerinin geldiği noktadan çok da memnun değillerdir.

Komşuluk ilişkileri bizim topraklarımızda yüzyıllardır devam eden önemli bir olgudur. Toplumsal değişim ve dönüşüm süreçleri son zamanlarda komşuluk ilişkilerinin daha farklı bir zemine oturmasına neden olsa da komşuluk ilişkileri devam etmektedir. $\mathrm{Bu}$ süreçte yeni neslin bu kültürü algılayıp edinmesinde toplumun çok farklı kesimlerine büyük rol düşmektedir.

\section{Kaynakça}

Akın, M. (2014). Komşuluk Kültürü. İçinde: Bir Toplumsallaşma Aracl Olarak Komşu, Ed: Ahmet Koyuncu, Ankara: Hece Yayınları.

Alver, K. (2012). Kent Sosyolojisi. İçinde: Kent İmgesi, Ed.: Köksal Alver, Ankara, Hece Yayınları.

Aydemir, M. A. (2014). Komşuluk ve Sosyal Sermaye, Komşuluk Kültürü. Ed: Ahmet Koyuncu, Ankara: Hece Yayınları.

Aydın, M. (2013). Dramdan Ütopyaya Komşuluğun Dönüşümü. Sosyoloji Divanı, 1(2), 37-54.

Çoban, H. ve İrmiş, A. (2015). Girişimcilik Kültürü Açısından Geleneksel Alışveriş Yerlerindeki Esnaf ile Modern AVM'lerdeki Esnafin Karşılaştırılması. İşletme ve Bilişim Yönetimi Dergisi, Say1: 1, 29-38. 
Koyuncu, A. (2013). Gündelik Hayatta Komşuluk. Sosyoloji Divanı, 1(2), 9-22.

Newman, D. M. (2016). Sosyoloji: Günlük Yaşamın Mimarisini Keşfetmek. Ali Arslan (Çev.). Ankara: Nobel Yayınlari.
Özdemir, R. (1986), Ankara Esnaf Teşkilatı. Milli Türkoloji Kongresi, İstanbul,156- 181.

Savaş, A. (2014). Tarihten Günümüze Komşuluk Hukuku, Komşuluk Kültürü. Ed: Ahmet Koyuncu, Ankara: Hece Yayınları.

\section{EK-1: ARAŞTIRMA VE YAYIN ETİĞİ KURUL KARARI}

T.C.

NECMETTIN ERBAKAN ÜNIVERSITESİ REKTÖRLÜĞÜ

Sosyal ve Beşeri Bilimler Araştırma ve Yayın Etiği Kurulu

ARASTTIRMA VE YAYIN ETIǴİ KURULU KARARI

\begin{tabular}{|c|c|c|c|}
\hline Toplantı Sayısı & $: 77$ & Toplant Tarihi & : 31.8 .2020 \\
\hline Karar Sayısı & : 2020/67 & & \\
\hline
\end{tabular}

Necmettin Erbakan Üniversitesi Sosyal ve Beşeri Bilimler Fakültesi Dr. Öğr. Üyesi Uğur ÇAĞLAK'ın hazırlayacağı "Esnaflar Arası Komşuluk Îliş̧ileri: Konya Bedesten Çarşısı Üzerine Bir Değerlendirme" adlı araştırma için etik kurul onayı verilmesi talep edilmiştir. Söz konusu başvuru Prof. Dr. Abdulkadir BULUŞ'un raporu dikkate alınarak görüşülmüştür. Başvuru dosyası ve ilgili belgeler araştırmanın gerekçe, amaç, yaklaşım ve yöntemleri dikkate alınarak incelenmiş olup, araştırmanın gerçekleștirilmesinde etik sakınca bulunmadığına ve araştırmaya etik kurul onayı verilmesine oy birliği ile karar verilmiştir.

\section{e-imzalıdır}

Prof. Dr. Zekeriya MIZIRAK

Etik Kurulu Başkanı

Adres: Dere Aşıklar Mah. Demę̧ Sok. No:42 Meram/KONYA 